\title{
Thermal stress in the adequacy of the chemical scarification period in brachiaria seeds
}

\section{Adriana Hemandes Pinto ${ }^{1}$, Thiago Barbosa Batista ${ }^{2}$, Flávio Ferreira da Silva Binotti ${ }^{3}$, Eliana Duarte Cardoso Binotti ${ }^{3}$, Edilson Costa ${ }^{3}$}

\author{
${ }^{1}$ Centro Universitário Una, Campus de Jataí, Jataí, Goiás, Brasil. E-mail: adriana-hpinto@ hotmail.com \\ ${ }^{2}$ Universidade Estadual Paulista "Júlio de Mesquita Filho", Faculdade de Ciências Agronômicas de Botucatu, Botucatu, São Paulo, \\ Brasil. E-mail: batistatb@hotmail.com \\ ${ }^{3}$ Universidade Estadual de Mato Grosso do Sul, Unidade Universitária de Cassilândia, Cassilândia, Mato Grosso do Sul, Brasil. E- \\ mail: binotti@uems.br,dcllia78@y ahoo.com.br, mestrine@uems.br
}

Received: 14/12/2020; Accepted:19/02/2021.

\section{ABSTRACT}

Forage seeds often have a low germination percentage due to their seeds' dormancy, such as seeds of the genus Urochloa. Chemical scarification is chosen to overcome the dormancy, yet the seed's vigor level is not taken into account. On this wise, the method can harm the seed's quality. In this context, the study aimed to investigate the appropriate scarification period in brachiaria seeds and how the lot's thermal stress can affect this result. The experimental design was completely randomized, arranged in a $3 \times 4$ factorial scheme, designated by thermal stress $(0,24$, and 48 hours $)$ and periods of chemical scarification with concentrated sulfuric acid $(0,5,10$, and 15 minutes), with four repetitions. After scarification of the treatments, the seeds were evaluated for germination and vigor criteria. Scarification for 5 minutes is enough to express the quality of Urochloa brizantha cv. MG-5. This technique is not recommended after the seeds are severely stressed by temperature and humidity.

Keywords: Urochloa brizantha, overcoming dormancy, physiological quality.

\section{Estresse térmico na adequação do período de escarificação química em sementes de braquiária}

\section{RESUMO}

Sementes forrageiras muitas vezes têm baixo percentual de germinação devido à dormência de suas sementes, como as sementes do gênero Urochloa. Para superar este desafio opta-se pela escarificação química, todavia não se leva em consideração o nível de vigor das sementes e desta forma o método pode prejudicar a qualidade das sementes. Neste contexto, o trabalho objetivou investigar adequado período de escarificação em sementes de braquiária e como o estresse térmico no lote pode afetar este resultado. O delineamento experimental foi o inteiramente casualizado, em esquema fatorial 3x4, designado por: estresse térmico (zero, 24 e 48 horas) e períodos de escarificação química com ácido sulfúrico concentrado (zero, 5, 10 e 15 minutos), com quatro repetições. Após aplicação dos tratamentos as sementes foram avaliadas quanto aos critérios de germinação e vigor. A escarificação pelo período de 5 minutos é suficiente para expressão da qualidade de sementes de Urochloa brizantha cv. MG-5. Esta técnica não é recomendada após as sementes sofrerem estresse severo por temperatura e umidade.

Palavras-chave: Urochloa brizantha, superação de dormência; qualidade fisiológica. 


\section{Introduction}

Brachiaria seeds present dormancy, which prevents adequate germination resulting in the uneven formation of the plant stand. In these seeds, dormancy occurs due to wraps, which have in their composition some chemical compounds that hinder the gases diffusion during the beginning of germination (Marcos-Filho, 2015). It has been recognized that in forage species, dormancy is more pronounced in freshly harvested seeds and is overcome during storage, as demonstrated by Vieira et al. (1998) and Luccas et al. (2018).

Depending on market demand, seed storage is often not feasible or too short and must be marketed freshly harvested, in which case, it is necessary to have treatments to overcome seed dormancy. Maeda and Pereira (1997) showed that the removal of the motto and/or pale could increase the germination of Pasparum notarum seeds by up to $80 \%$, and the removal of these structures can be accomplished by chemical scarification with concentrated sulfuric acid (the method most used in seeds for exportation). This method allows the immediate commercialization of the freshly harvested lots and improves the seeds' appearance by removing the integrals present. Also, chemical scarification can reduce the seeds as sociated pathogens incidence (Sbalcheiro et al., 2014).

For species of the Urochloa genus, chemical scarification with concentrated sulfuric acid must be carried out for a maximum of 15 minutes according to the Seed Analysis Rule's recommendation (Brasil, 2009). In the literature, different scarification periods are used within the recommended range. Chemical scarification for five minutes in sulfuric acid in the studies by Binotti et al. (2014) led to the overcoming of dormancy of the seeds of Urochloa brizantha. Sallum et al. (2010) found that chemical scarification with sulfuric acid for 5, 10, and 15 minutes promotes the germination of the seeds of Urochloa brizantha cv. "Marandu".

Studies with overcoming dormancy focus on the method's assertiveness to increase germination rates, and little are considered regarding the lot's vigor. Vigor includes several characteristics, such as uniformity and germination speed, seedling growth, emergence in the field, tolerance to adverse conditions, and the ability to remain viable during storage. Through these features, vigor is indirectly relevant to crop production given by the adequate seedlings' emergence (Finch-Savage and Bassel, 2016). The events leading to the seeds' deterioration start from the harvest (Marcos-Filho, 2015), causing irreversible losses regarding their vigor. These losses can still be accelerated due to the stress imposed on the lot.

Seed storage facilities can expose seeds to stress (mainly thermal), leading to a significant reduction in seed vigor. Thus, during storage, between harvest and commercialization, although sometimes for a short time, the seeds may suffer vigor-related losses, particularly in forages, which must undergo chemical scarification before being commercialized. A punctual reduction in the seeds' vigor must be taken into account when deciding for the scarification period to be adopted since, theoretically, a change in this component may draw a need to adjust the scarification period.

Conclusive information about the exact period in which the seeds of Urochloa brizantha cv. MG-5 can be exposed to chemical scarification without its physiological performance and its plasticity being affected to the detriment of the seeds' vigor is still incipient. Thus, the objective was to investigate which scarification period is suitable for Urochloa brizantha MG-5 and how a stress-imposed seed vigor distinction due to high temperature and humidity can affect this technique.

\section{Material and Methods}

Seeds of Urochloa brizantha cv. MG-5, harvested by the scanning method in the 2013/2014 harvest, were used. The initial physiological characteristics of the seeds were: water content $=11 \%$; viability $=89 \%$; total germination: $42 \%$; germination speed index $=2.25$.

The experimental design was completely randomized, arranged in a 3x4 factorial scheme, designated by thermal stress (absence, 24, and 48 hours) and scarification periods (control - without scarification, 5,10 , and 15 minutes), with four repetitions.

For thermal stress, accelerated aging was used, with the seeds being placed on a wire mesh suspended in a gerbox containing water at $41{ }^{\circ} \mathrm{C}$ and with a relative humidity of $\pm 98 \%$. After applying the treatments, the seeds were placed in a laboratory environment to resume the water content of $11 \%$, determined according Brasil (2009).

Chemical scarification was performed by immersing the seeds in concentrated sulfuric acid $\left(\mathrm{H}_{2} \mathrm{SO}_{4}\right)$. After scarification, the seeds were washed in deionized water and placed to dry in a laboratory environment to resume the equilibrium water content of $11 \%$. After the application of the treatments, the seeds were evaluated for their physiological characteristics described in sequence.

The germination test was carried out with four samples of 50 seeds, placed on paper moistened in a plastic box. The test was conducted at $25^{\circ} \mathrm{C}$, and the counts were performed at seven (first germination count-FG) and 21 days (total germination-TG) after installation, according to the criteria established by the Seed Analysis Rules (Brasil, 2009). The germination speed index (GSI) adapted from Maguire (1962) was calculated from the cumulative germination data. 
The germination test's remaining seeds were cut longitudinally and submitted to the tetrazole test, following criteria established by Brasil (2009) for Urochloa brizantha. The percentage of viable (dormant) and non-viable seeds remaining from the germination test was determined (Batista et al., 2016).

The seedling emergence was carried out in a screened nursery with $50 \%$ shade (black Sombrite ${ }^{\circledR}$ type screen), using four samples of 50 seeds, sown in trays with vermiculite substrate. The percentage of emerged seedlings was registered until their emergence stabilized at seven days (first emergence count-FE) with a limit of 28 days after sowing (total emergence-TE), considering as emerged seedlings those that presented with shoot length not less than $20 \mathrm{~mm}$. The results were expressed as a percentage of emerged seedlings. Using the cumulative emergence data, the emergence speed index (ESI) adapted from Maguire (1962) was calculated.

The data were submitted to the Shapiro-Wilk normality test. Analys is of variance was performed, and when the $\mathrm{F}$ test was significant, the averages were compared using the t-test (LSD) at a confidence level of 0.05 . For the statistical procedure, the percentage variables were transformed into an $\arcsin \sqrt{ }(\mathrm{x} / 100)$.

\section{Results and Discussion}

The analysis of variance showed that the effects of stress and chemical scarification period were significant ( $\mathrm{p}<0.05$ ) in all analyzed variables (Table 1), with significant interaction $(\mathrm{p}<0.05)$ for all germination characteristics and emergence, except for the first germination count and germination speed index. (Table 1).

A significant interaction between thermal stress and chemical scarification for most of the physiological characteristics related to the physiological performance of brachiaria seeds was found. This result indicates that there is a variation in chemical scarification response at different levels of stress.

Chemical scarification for 5 and 10 minutes increased the germination percentage of the brachiaria seeds. The germination percentage was $\geq 80 \%$ in the absence of stress, which fits the commercial standard rates. Chemical scarification for $5 \mathrm{~min}$ can be used in seeds that are not subjected to stress and submitted to it for 24 hours since the resulting germination reaches an acceptable commercialization rate. In contrast, the 10 min period only promoted a significant increase in germination in non-stressed seeds (Figure 1A).

An increase in germination rates (Figure 1A) is associated with overcoming dormancy and a consequent reduction in the percentage of remaining unviable seeds promoted by scarification of 5 and $10 \mathrm{~min}$ (Figure 1B and $\mathrm{C}$ ). The maximum period recommended by the
Seed Analysis Rule for forage species of 15 min was the treatment that reduced the germination rates due to an increase in the remaining unviable seeds rate (Figure 1), regardless of the imposed stress.

Using the maximum period of 15 min recommended by Brazil (2009), Silva et al. (2014) found that chemical scarification was the most efficient method for promoting seed germination of different cultivars of Urochloa brizantha. However, the germination percentages of Silva et al. (2014) were below the rates verified in the current study (Figure 1A).

In the literature, it is possible to verify that chemical scarification with concentrated sulfuric acid for 5 minutes has been used efficiently to overcome the seeds' dormancy of Urochloa brizantha cv. MG-5 (Cardoso et al., 2014, Binotti et al., 2014). This reduction in the time employed for scarification in lesser exposure of the seed to sulfuric acid makes the process faster. According to this study's results, this time implies higher germination percentages regarding the maximum period recommended by the Seed Analysis Rule (Brazil, 2009).

Sallum et al. (2010) found that the seeds' immersion in sulfuric acid for 5, 10, and 15 min results in increased germination for Urochloa brizantha cv. 'Marandu'. This result differs from Lacerda et al. (2010), who found that treatments with sulfuric acid for 5 and 10 minutes were not efficient in promoting germination regarding the other treatments applied in Urochloa brizantha cv. 'Marandu' seeds.

These findings indicate the existence of distinct mechanisms associated with dormancy in the seeds of forage species. Glison et al. (2017) found a difference concerning dormancy between Paspalum dilatatum genotypes due to the motto's incidence. Luccas et al. (2018) demonstrated that in Urochloa humidicola, dormancy involves the remaining structure of the caryopsis and the increase in the growth potential of the embryo during storage in addition to the gibberellin and abscisic acid (promoter/inhibitor) balance. To summarize, there is a natural occurrence in the intensity and dormancy type among forages, which explains why there are different responses concerning the scarification period between the cultivar MG-5 used in the present study, compared to the recommendations for cultivating Marandu.

Brachiaria seeds without thermal stress obtained a higher germination percentage at seven days (first count) and germination speed index (Figure 2). These results demonstrate that the applied stress altered the vigor level in the brachiaria seeds, validating the stress action due to high temperature and relative humidity in this parameter's decreased values. Chemical scarification for 5 and 10 minutes promoted an increase in the seed germination percentage at first count and germination speed (Figure 2). 
Table 1. Summary of the analysis of variance for the germination and emergence characteristics of Urochloa brizantha cv. MG-5 due to thermal stress and chemical scarification of seeds.

\begin{tabular}{|c|c|c|c|c|c|c|c|c|}
\hline \multirow{2}{*}{ Source of variation } & \multicolumn{8}{|c|}{ Probability > F } \\
\hline & FG & TG & Dormants & Inviabless & GSI & $\overline{F E}$ & $\mathrm{TE}$ & ESI \\
\hline Thermal stress & $<0.0000$ & $<0.0000$ & 0.0001 & 0.0037 & $<0.0000$ & $<0.0000$ & $<0.0000$ & $<0.0000$ \\
\hline Scarification & $<0.0000$ & $<0.0000$ & $<0.0000$ & $<0.0000$ & $<0.0000$ & $<0.0000$ & $<0.0000$ & $<0.0000$ \\
\hline $\begin{array}{l}\text { Thermal stress } \mathrm{x} \\
\text { Scarification }\end{array}$ & 0.8503 & 0.0249 & 0.0034 & $<0.0000$ & 0.3558 & $<0.0000$ & 0.0016 & $<0.0000$ \\
\hline C.V.\% & 26.13 & 19.06 & 33.95 & 23.00 & 17.47 & 22.43 & 16.53 & 15.64 \\
\hline
\end{tabular}
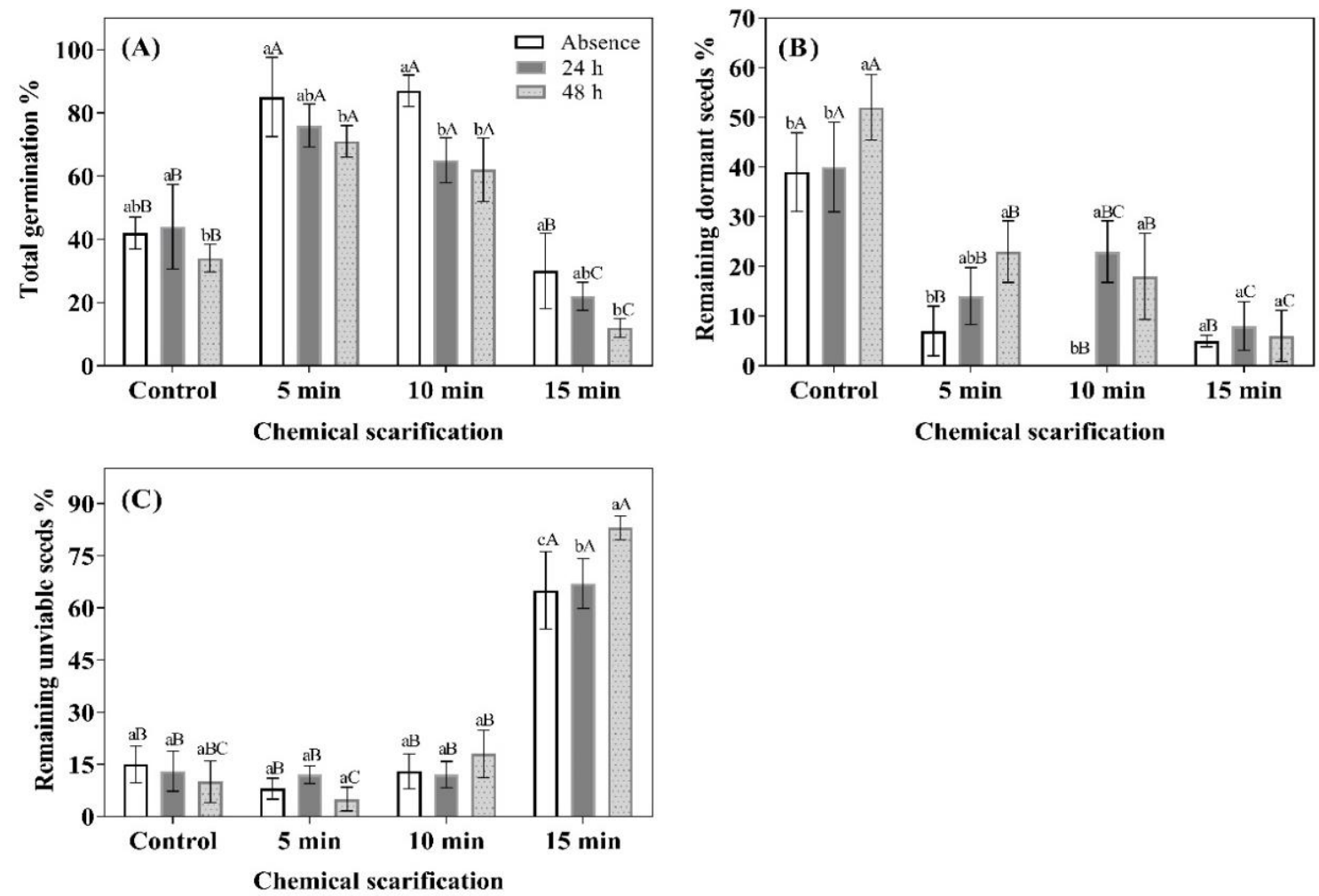

Figure 1. Effect of thermal stress and chemical scarification period on total germination (A), dormant (B), and non-viable (C) Urochloa brizantha seeds. Bars followed by the same lowercase letter between aging or the same uppercase letter for chemical scarification do not differ by the $t$-test at the 0.05 confidence level. Data refer to mean values $(n=4) \pm$ standard deviation.
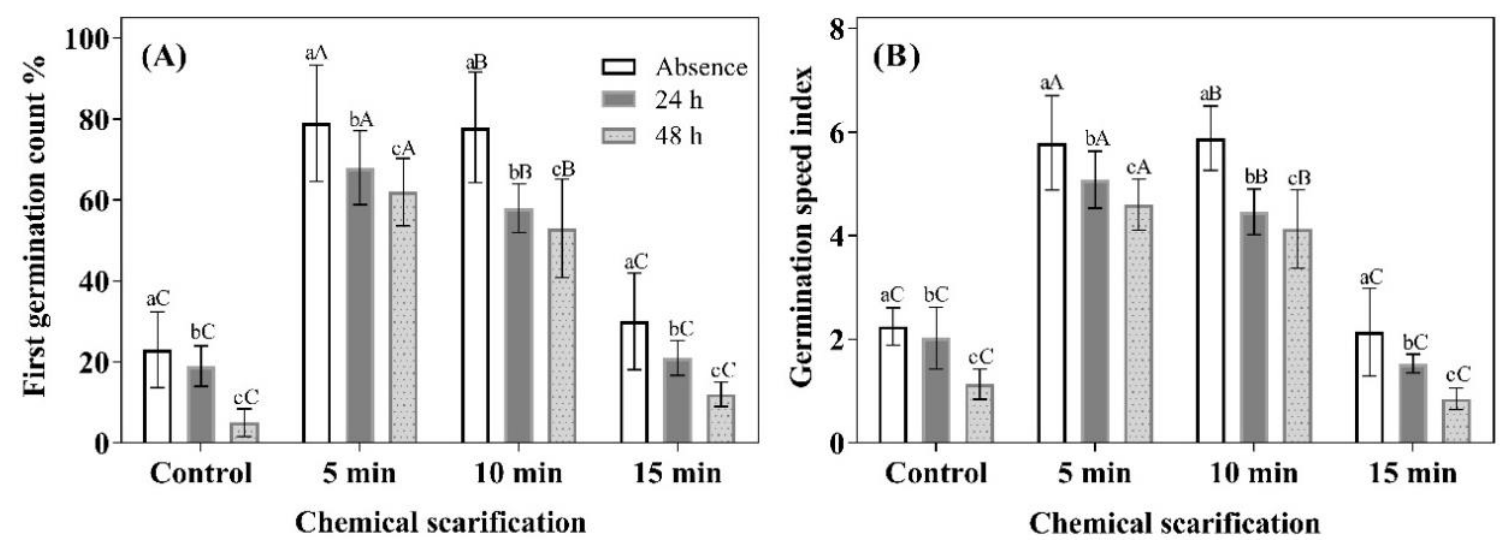

Figure 2. Effect of thermal stress and chemical scarification period on the first germination count (A) and germination speed index (B) of Urochloa brizantha seeds. Bars followed by the same lowercase letter between aging or the same uppercase letter for chemical scarification do not differ by the t-test at the 0.05 confidence level. Data refer to mean values $(n=4) \pm$ standard deviation. 
Similar to that found in the present study, Binotti et al. (2014) found that Urochloa brizantha cv. MG-5 seeds' chemical scarification for 5 minutes provided an increase in the first germination count and the germination speed, relating it to a higher imbibition speed by removing glumella and/or pericarp by chemical scarification with sulfuric acid.

In the literature, it is common to see that dormancy in forage species is associated with water entry restriction imposed by glumella and/or pericarp. However, this concept has been questioned as knowledge progresses. Currently, dormancy in forage species is associated with the limitation of the oxygen and/or carbon dioxide movement imposed by the integument structure and/or chemical composition and even the tissues surrounding the embryo (Marcos-Filho, 2015).

As proven, seed storage is already practiced for overcoming forage species' dormancy (Vieira et al., 1998), so the blocking of germination is more involved with inhibitors resent in the seeds and, as the exposure to seed aging increases, these compounds activity is inhibited. Thus, chemical scarification for a period of 5 and $10 \mathrm{~min}$ resulted in adequate germination and an increase in germination speed (Figures 1 and 2) due to the elimination of the physical barrier and inhibitors present; the protrusion of the primary root and consequent seedling formation occurred without impediment in a faster way.
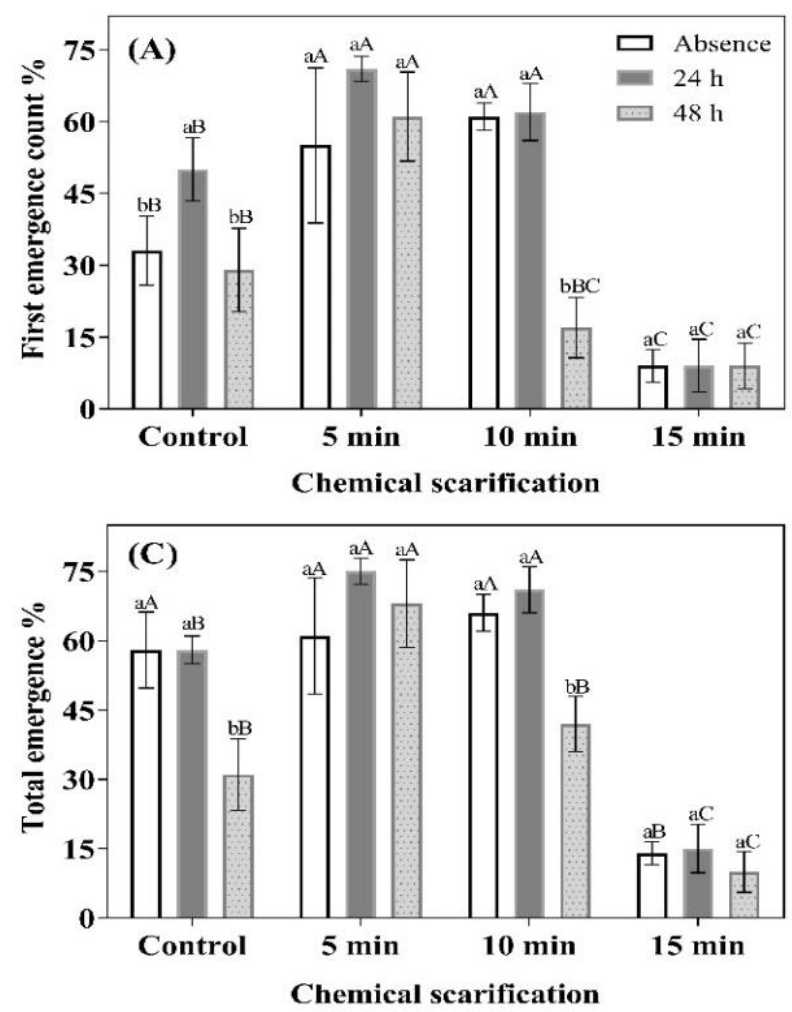

Accelerated aging $\left(41^{\circ} \mathrm{C}\right)$ promotes an increase in the germination and emergence speed of non-scarified seeds of Urochloa brizantha cv. MG-5 (Cardoso et al., 2014). This discrepancy between the promotion and reduction of the seeds' physiological quality due to the stress caused by high temperature and humidity is related to the intensity of dormancy at the experiment installation time.

The present study's seeds had lower dormancy than the study by Cardoso et al. (2014). For this reason, stress, which can primarily help overcome dormancy, reduced the physiological quality of seeds. Chemical scarification for 5 and 10 minutes increased the percentage of seedlings that emerged at seven days and increased the emergence speed rate in seeds not subjected to thermal stress (Figure 3A and 3B). Scarification for $5 \mathrm{~min}$ increases the emergence of brachiaria seeds that have previously undergone thermal stress (Figure 3).

This result is important since when the vigor is moderately reduced in the seed lot, the chemical scarification technique should not be discarded. Even if the lot does not fit the commercial standard, this procedure increases emergence rates, directly influencing the plant stand establishment, allowing these seeds' use.

In general, chemical scarification for 15 minutes was detrimental to the physiological quality of brachiaria seeds, evidenced by the decrease in germination, vigor, emergence, and an increase in the number of unviable seeds (Figures 1, 2, and 3).

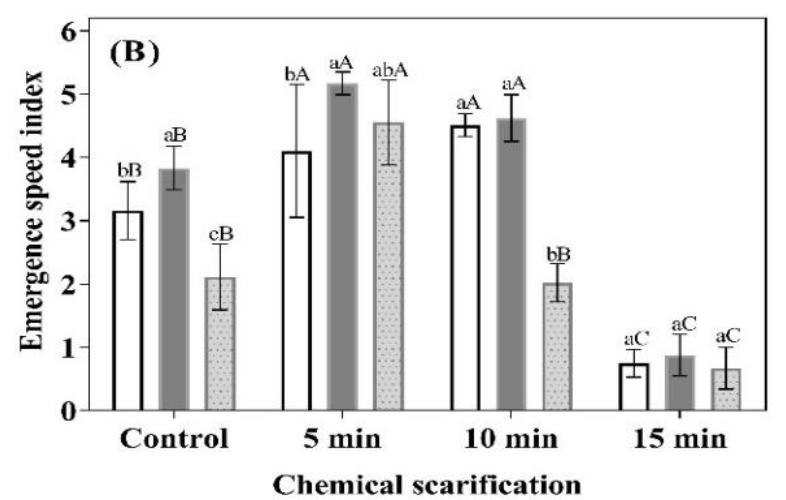

Chemical scarification

Figure 3. Effect of thermal stress and chemical scarification period on the first emergence count (A), emergence speed index (B), and total emergence of Urochloa brizantha seeds. Bars followed by the same lowercase letter between aging or the same uppercase letter for chemical scarification do not differ by the t-test at the 0.05 confidence level. Data refer to mean values $(n=4) \pm$ standard deviation. 
Hypothetically, the cultivar used in the present study has a lower dormancy intensity, and the chemical scarification exposure for 15 minutes was very severe after the integuments removal, promoting a seeds' physiological potential reduction.

Thus, it was possible to verify that 15 minutes is the least suitable period for Urochloa brizantha cv. MG-5 seeds, regardless of their vigor level. The short period of 5 minutes is the most viable to be used due to increased germination and emergence characteristics in the seeds. It is also enabled to use in seeds having suffered high temperature and humidity stress for a short period $\left(41^{\circ} \mathrm{C} / 24\right.$ hours $)$.

\section{Conclusions}

Chemical scarification for 5 minutes is sufficient to allow better expression of Urochloa brizantha cv. MG-5 physiological potential; seeds with a severe and significant vigor reduction should not be scarified.

\section{Authors' Contribution}

Adriana Hernandes Pinto performed and designed the experiments, data collection, formal analysis and writing of the original draft. Thiago Barbosa Batista performed formal analysis, validation, writing review and editing. Flávio Ferreira da Silva Binotti performed funding acquisition, project design and experiments, supervision, writing - review and editing. Eliana Duarte Cardoso Binotti and Edilson Costa performed review of the manuscript equally.

\section{Acknowledg me nts}

To Matsuda for providing seeds for the experiments. Fundação de Apoio ao Desenvolvimento do Ensino, Ciência e Tecnologia do Estado de Mato Grosso do Sul (Fundect), for the financial support (UNIVERSAL-MS and PIBIC/UEMS/Fundect).

\section{Bibliographic References}

Batista, T.B., Binotti, F.F.S., Cardoso, E.D., Costa, E., Nascimento, D.M. 2016. Appropriate hydration period and chemical agent improve priming in brachiaria seeds. Pesquisa Agropecuária Tropical, 46 (3), 350-356. DOI: http://dx.doi.org/10.1590/1983-40632016v4638422

Binotti, F.F.S., Sueda Junior, C.I., Cardoso, E.D., Haga, K.I., Nogueira, D. 2014. Tratamentos pré-germinativos em sementes de Brachiaria. Revista Brasileira de Ciências Agrárias, 9 (4), 614-618. DOI: http://dx.doi.org/10.5039/agraria.v9i4a2781

BRASIL. MINISTÉRIO DA AGRICULTURA, PECUÁRIA E ABASTECIMENTO. 2009. Regras para análise de sementes. Ministério da Agricultura, Pecuária e
Abastecimento. Secretaria de Defesa Agropecuária. Brasília: MAPA/ACS, 2009.

Cardoso, E.D., Sá, M.E., Haga, K.I., Binotti, F.F.S., Nogueira, D.C., Valério Filho, W.V. 2014. Desempenho fisiológico e superação de dormência em sementes de Brachiaria brizantha submetidas a tratamento químico e envelhecimento artificial. Semina: Ciências Agrárias, 35 (1), 21-38. DOI: http://dx.doi.org/10.5433/1679-0359.2014v35n1p21

Finch-Savage, W. E., Bassel, G. W. 2016. Seed vigour and crop establishment: Extending performance beyond adaptation. Journal of Experimental Botany, 67 (3), 567-591. DOI: https://doi.org/10.1093/jxb/erv490

Glison, N., Viega, L., Speranza, P. 2017. Differential incidence of the lemma on seed germination among different Paspalum dilatatum genotypes. Journal of seed science, 39 (2), 133-141. DOI: http://dx.doi.org/10.1590/2317-1545v39n2169225

Lacerda, M.J.R., Cabral, J.S.R., Sales, J.F., Freitas, K. R., Fontes, A. J. 2010. Superação de dormência de sementes de Brachiaria brizantha cv. "Marandu". Semina: Ciências Agrárias, 31 (4), 823-828. DOI: http://dx.doi.org/10.5433/1679$0359.2010 \mathrm{v} 31 \mathrm{n} 4 \mathrm{p} 823$

Luccas, D. A., Oliveira, J.P.R., Silveira, L.E.D., Silva, E.A.A. 2018. An integrative insight on dormancy alleviation in diaspores of Urochloa humidicola (Rendle) Morrone \& Zuloaga, a tropical grass with great economic and ecological impact. Plant Biology, 20 (2), 252-262. DOI: https://doi.org/10.1111/plb.12655

Maeda, J.A., Pereira, M.F.D.A. 1997. Caracterização, beneficiamento e germinação de sementes de Paspalum notatum Flügge. Revista Brasileira de Sementes, 19 (1), 100-105. DOI: http://dx.doi.org/10.17801/0101-3122/rbs.v19n1p100-105

Maguire, J.D. 1962. Speed of germination aid in selection and evaluation for seedling emergence and vigor. Crop Science, 2 (2), 176-177. DOI: https://doi.org/10.2135/cropsci1962.0011183X000200020033x

Marcos-Filho, J. 2015. Fisiologia de sementes de plantas cultivadas. Londrina: Abrates.

Sallum, M.S.S., Alves, D.S., Agostini, E.A.T., Machado Neto, N.B. 2010. Neutralização da escarificação química sobre a germinação de sementes de Brachiaria brizantha cv. 'Marandu'. Revista Brasileira de Ciências Agrárias, 5 (3), 315-321. DOI: http://dx.doi.org/10.5039/agraria.v5i3a603.

Sbalcheiro, C.L., José, S.C.B.R., Barbosa, J.C.R.C.M. 2014. Physiological and sanitary quality, and transmission of fungi associated with Brachiaria brizantha (Hochst. ex. A. Rich.) Stapf seeds submitted to thermal and chemical treatments. Journal of seed Science, 36 (4), 443-450. DOI: http://dx.doi.org/10.1590/2317-1545v36n41032

Silva, A.L.M.S., Torres, F.E., Garcia, L.L.P., Mattos, E.M., Teodoro, P.E.T. 2014. Tratamentos para quebra de dormência em Brachiaria brizantha. Revista de Ciências Agrárias, 37 (1), 37-41. DOI: https://doi.org/10.19084/rca.16797

Vieira, H.D., Silva, R.F., Barros, R.S. 1998. Efeito de substâncias reguladoras de crescimento sobre a germinação de sementes de braquiarão cv. Marandu. Revista Brasileira de Fisiologia Vegetal, 10 (2), 143-148. 